\title{
THE INNOVATION OF TEACHING MATERIALS BASED ON LOCAL WISDOM FOR DISASTER MITIGATION SUBJECT
}

\author{
Amanda Widyawardana ${ }^{1}$, Ardyanto Tanjung ${ }^{2}$, Syamsul Bachri ${ }^{3}$ \\ ${ }^{1,2,3}$ Department of Geography, Faculty of Social Science, Universitas Negeri Malang \\ Email: amandawidyawardana@gmail.com
}

\begin{abstract}
Teaching material is one of the learning components that used to assist the students understand a material. To fulfill this function, at least the material provided is relevant to the students' daily life. Therefore, it is necessary to develop teaching material that meets the concept of contextual learning. The purpose of this research was to produce teaching materials that are suitable to be used by developing a base of local wisdom. Local wisdom were chosen due to they are related to the concept of disaster mitigation, and are close to the students' daily life. Research method used the Borg \& Gall stage which was then adapted into, (1) collecting information and need analysis; (2) planning; (3) teaching material development; (4) prototype testing; (5) prototype revision; (6) model testing; (7) model revision. Through this stage, research product in the form of teaching materials was assessed for its feasibility by several experts and also tested on students as users. Product is targeted to gain a positive response from users with an average score above $70 \%$ which indicates that it is quite feasible to be implemented in learning, so that it may be an alternative as a learning resource besides using other textbooks.
\end{abstract}

Keywords: Disaster Mitigation; Local Wisdom; Teaching Material

\section{A. INTRODUCTION}

Teaching material is one of the learning components used to assist the students for understanding a material. The understanding of teaching materials can also be interpreted as all materials (information, tools, and texts) that are arranged systematically and show the integrity of the competencies mastered by students, so that it can be used for planning and reviewing the implementation of learning (Prastowo, 2015). The materials consist of facts, concepts, principles / rules, procedures, and problems which are packaged in the form of content or subject matter.

This research focuses on designing the teaching materials by developing a base of local wisdom. The existence of these teaching materials is considered essential when it is related to the implementation of learning with a contextual approach. Contextual signifies that the concept of learning can help the students to build knowledge based on the events that undergone and it can be applied in everyday life (Sulistyowati \& Putri, 2018). To make it 
happen, the educator's effort is needed in analyzing the need and raising local wisdom, particularly in the area of students' life (Tanjung \& Fahmi, 2015).

The development of this teaching material is an effort to build students' knowledge about their own area. In relation to contextual learning, students are able to understand geography material from the point of view of local wisdom. As a teacher, this consideration is important considering that learning related to the conditions around students is quite effective in the field. This can stimulate students' understanding of the subject matter more quickly.

Local wisdom means a system in the order of social, political, cultural, economic and environmental life in the midst of local communities (Thamrin, 2013). In relation to the environment, local wisdom provides a wise attitude in sustainable management and protection. In the discussion of modern geography, this is called a reciprocal relationship between humans and the environment (Butzer, 1982).

Globalization erodes old knowledge that has been applied by the ancestors. It only impacts on few people that know about the meaning of a behaviour and build it as a customary habit. Even if it wants to be explored, many messages are obtained from a behaviour that has been carried out from generation to generation. In fact, this inherited behaviour can maintain environmental balance (Parmin et al., 2016).

Globalization also provides attraction in the form of new knowledge and foreign cultures. With this attraction, local wisdom may be neglected as industry and technology progress in the future (Pornpimon et al., 2014). Thus, the local wisdom that was previously neglected should be attempted to become a proper science in guarding national development in a more efficient direction. Dealing with the issue, it provides prosperity development appropriately in accordance with the local requirements.

Educational demand currently requires the student-centered learning. Students are placed as subjects who have an interest and potential in active development. In this regard, the students need the role of teachers as facilitators and supervisor in overcoming learning barriers (Dewi \& Hamami, 2019). To support this case, the teachers need to provide appropriate resources and support this activity.

In fact, the resources used is it does not support learning well. First, the 
learning resources provided specifically by schools in the form of textbooks, still provide theory and case studies generally. In this case, theories or case studies are still general and need more development from a teacher. However, another problem arises, when all teachers do not have the ability to develop their teaching materials from these learning resources. There are many teachers who still use teaching materials from other people or manufacturers and are not in accordance with the sociocultural students (Prastowo, 2015).

Especially in disaster mitigation material, the books provided have not been able to support the understanding of disaster management in the area around students. The material provided still contains definitions of disasters, principles or stages of mitigation, and discussion of local wisdom in general. The content of the material is deemed not yet present the area where students live, so additional information is needed to deal with this problem. Therefore, the existence of teaching materials to support contextual understanding related to disaster mitigation, especially in areas where students live, is quite important to develop.

The output produced from this research is a good teaching material that supports student learning activities. With the subject of geography, teaching materials based on local wisdom have a close relation with the materials taught in it. This base appears due to it is related to answer the geosphere phenomenon that varies in every place.

The appropriate material for the content of this teaching material is disaster mitigation. Disaster mitigation is considered suitable when juxtaposed with the concept of local wisdom and the environment. Local wisdom includes a form of adaptive behaviour to the environment that can be used as a role in disaster risk reduction (Suarmika \& Utama, 2017). Adaptation to disasters also indicates that the relationship between human and the environment, in which there is a human ecology approach.

Disaster mitigation and local wisdom are two matters that are quite important when it is combined. In relation to risk reduction, the local wisdom possessed by the community can be the first means of implementing disaster mitigation. The community is the main object when a disaster occurs, which has direct experience when it occurs. Their response to disasters is the beginning of an adaptation strategy generated through understanding when 
the phenomenon occurs (Desfandi, 2014).

The examples of the successful implementation of local wisdom in disaster mitigation can be found in several regions in Indonesia. In direct practice, exemplified by people in disaster-prone areas of Mt. Slamet, with household activities and the tradition of Ruwat Bumi in dealing with the volcanic activity of the mountain (Dewanti et al., 2019). Another example in terms of modification of hate training is in Pijoan Village, Muaro Regency, Jambi by implementing the PEER model (Program for Enhancement of Emergency Response) (Subandi et al., 2019). The concept of local wisdom as the basis for disaster mitigation has been widely practiced by the Indonesian people, and definitely there are environmental values in it.

Through the background above, the researcher intends to conduct research with the concept of developing teaching materials. This research is intended to provide a new variety of development research. There are many topics of development research, however, specifically on the topic of teaching materials, the percentage given is less than other types of topics in similar research, such as their relation to the media. Besides, if it is explored dealing with the educational research, this topic contributes less than other educational topics.

\section{B. MATERIALS AND METHODS}

The development of research model is a process used to develop and validate research products in order to it can be appropriate and better. Previous research products are only suitable for meeting the needs at that time, however these products are not necessarily able to be used effectively in the present conditions due to the factors that require product development and validation.

\section{Research Stage}

This study used the stages of Borg \& Gall. This method is included in the category of development research, which has the goal of producing a certain product and then its effectiveness is tested (Sugiyono, 2016). The Borg \& Gall model research was chosen, it was suitable for product-based development research conducted by university level researchers. One of the advantages is that the stages applied are quite comprehensive and coherent (Aka, 2019).

Based on a number of these stages, the researcher adapted it into seven parts consisting of: (1) information collection 
and needs analysis, (2) planning, (3)

teaching material development, (4) prototype testing, (5) prototype revision, (6) model testing, (7) model revision. The reason behind this is that the research was carried out only up to the first level trials by targeting students. Thus, the final stages related to mass production are not listed in this research and the results of the products are not commercial. In this realm, it enables that new corrective researches will emerge with the object within the scope of this research, so that it is expected that higher quality products can appear later on, especially teaching materials. In detail, the stages that are passed in this research are described as follows.

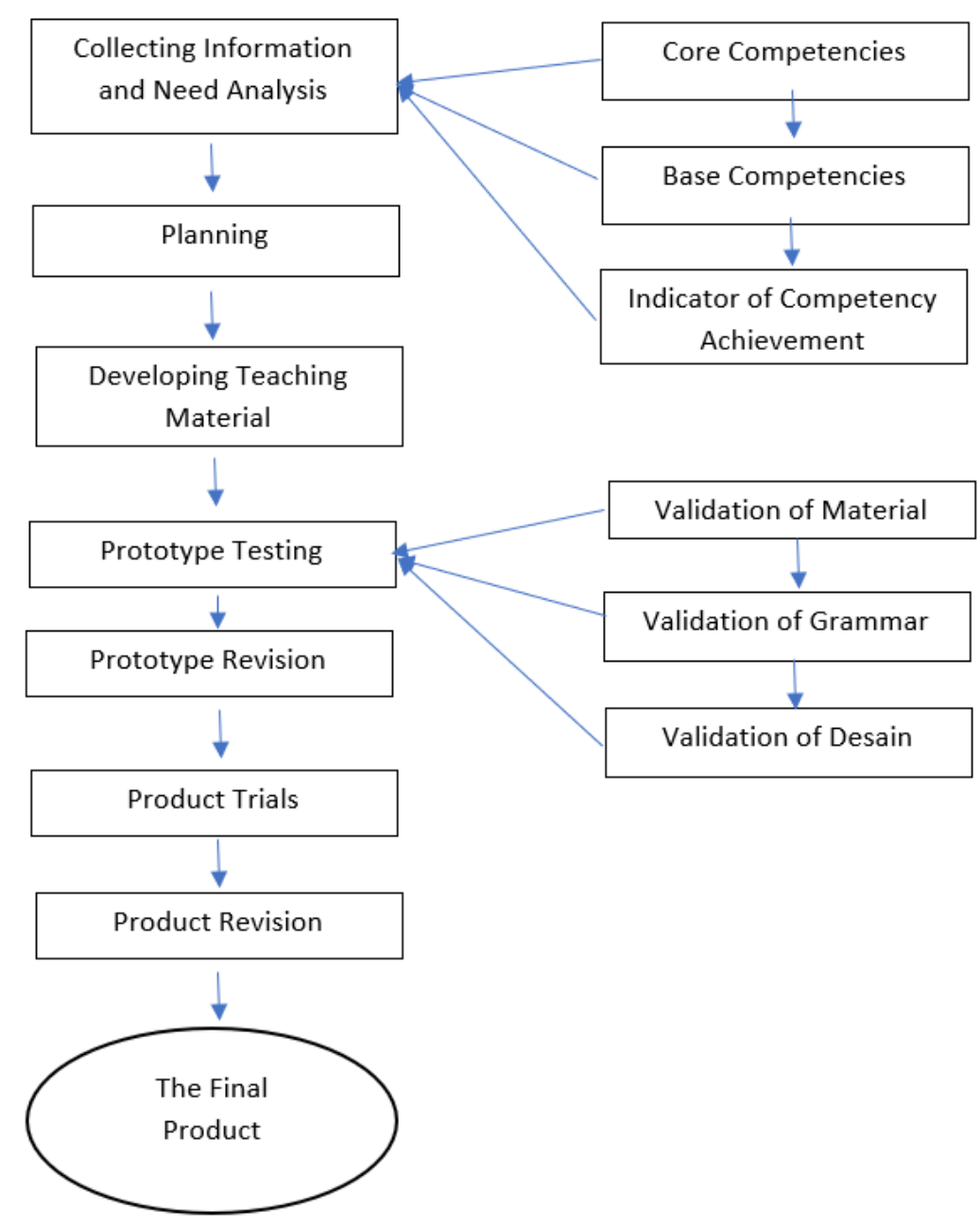

Source: (Setyosari, 2013)

Figure 1. Chart of Research and Development of Teaching Materials Adapted by Borg \& Gall 
1. Collecting information and needs analysis, are related to the elaboration of core competencies, basic competencies, and indicators, then analysis of the required product concepts.

2. Planning, is the design of a product framework based on the principles of relevance, consistency and adequacy for the content of teaching materials.

3. The development of teaching materials, contains the complete preparation of the products that will be tested later.

4. Prototype testing is an adaptation of Preliminary Field Testing, and consists of expert evaluation of materials, languages, and design for semi-finished products (prototypes).

5. Prototype revision, is the improvement of product based on the evaluation results of previous experts.

6. Model testing, is from the adaptation of the Main Field-Testing stage, namely testing on the research subjects to obtain responses and evaluate the usage of product

7. Revision of the model, is a follow up action to field trials in the form of product improvements based on the responses of research subjects.

8. The final product, is not a stage, but is intended to determine the final result of a teaching material product, and become a consideration plan for publication

\section{Type of Data}

The data used in the research on the development of teaching materials were in the form of quantitative and qualitative data. This data was obtained from a questionnaire of research subjects. Then, calculations were undertaken directly with percentages on quantitative data. Meanwhile, quantitative data was used to see the shortcomings of teaching material products.

\section{Data Collection Instruments}

The instrument in collecting research data, namely a questionnaire containing questions about the feasibility of the product. It aims to assess the quality of teaching materials from three aspects, namely the understanding of the material, language, and appearance. First, a special expert questionnaire containing indicators and comments on the feasibility of an essay product. Second, a special questionnaire for the test subjects (students) contains an indicator of the feasibility of the product as outlined in a multiple choice form.

\section{Data Analysis}

The source of the research data analysis was obtained from the results of indicator assessments by experts and test subjects (students). The expert assessment data uses the form of a qualitative essay, this is useful for researchers to improve products in detail and broadly. The test subjects' assessment data is quantitative in the 
form of multiple choices, this makes it easier for them to assess the feasibility of the product in a concrete way.

The data provided by experts in the form of indicator responses and product feasibility decisions. The decisions of the experts can be stated as follows.

a) Feasible to be used in the field without revision.

b) Feasible to be used in the field with revisions.

c) Not feasible to be used in the field and revision is recommended.

d) Not feasible to be used in the field.

Specific data analysis on the questionnaire of the test subjects used the data processing formula for each item's crossover and the overall data processing formula.
The crossover formula for each item :

$$
P=\frac{x}{x_{1}} \times 100 \%
$$

The overall data processing formula:

$$
P=\frac{\sum x}{\sum x_{1}} \times 100 \%
$$

\section{Description:}

$P=$ Percentage

$X=$ the total score of the subject's answers on one item of data

$X_{1}=$ the maximum score on one item of data

$\sum x=$ the total score of respondents' answers

$\sum \mathrm{x}_{1}=$ the total of maximum score

$100=$ constant

The conclusion is determined based on the assessment criteria from the percentage data which are described as follows.

Table 1. The Criteria of Decision Making for Product Feasibility

\begin{tabular}{cll}
\hline Classification & Score & Qualification \\
\hline A & $85,01-100,00$ & Very valid, or can be used without revision \\
\hline B & $70,01-85,00$ & $\begin{array}{l}\text { Quite valid, or can be used but needs a little } \\
\text { revision }\end{array}$ \\
\hline C & $50,01-70,00$ & $\begin{array}{l}\text { Less valid, it is recommended not to use it } \\
\text { because it needs major revisions }\end{array}$ \\
\hline D & $1,00-50,00$ & Not valid, or may not be used \\
\hline
\end{tabular}

Source: (Akbar, 2013)

If the analysis results have reached more than $70 \%$, the teaching materials produced are sufficiently suitable for use in classroom learning. These results take into account existing criteria, so that to achieve proper teaching materials, it does not only meet the appropriate criteria, but also be interesting and appropriate. Based on this regard, the development of teaching materials has met the development criteria so that it can be asserted to be feasible. 


\section{RESULT AND DISCUSSION}

The development research data described below is the result of validation of experts and students. The data obtained were in the form of quantitative and qualitative. For quantitative data, it was analyzed using a percentage formula. In contrast to qualitative, this data contained of the responses and suggestions which were then taken into consideration for further product development.

The Validation Result of Material Expert
Material validation was carried out to find out the feasibility of the material from the teaching material prototype. Especially in teaching materials, the material should provide experience or guidance to students to achieve learning goals (Saglam, 2011). Recommendation is needed for improving the initial prototype considering that the material is a vital part of a teaching material. The points that were taken into consideration in assessing this prototype.

Table 2. Assessment Items of the Expert

\begin{tabular}{cl}
\hline No & \multicolumn{1}{c}{ Assessment Items } \\
\hline 1 & The completeness and breadth of the material \\
\hline 2 & The detailed explanation of the material \\
\hline 3 & Accuracy of concepts, data and examples \\
\hline 4 & $\begin{array}{l}\text { The feasibility of the material with the } \\
\text { development of science }\end{array}$ \\
\hline 5 & Implementation in the daily life \\
\hline 6 & Up-to-date References \\
\hline 7 & Reading interest
\end{tabular}

The accuracy of concepts, data and examples is one of the most highlighted items. The researcher tended to examine foreign published books and deepened the data from related agencies. The reference book is used to support the accuracy of concepts and examples, while the agency data is used to strengthen the explanation of the material. This aims to increase the accuracy of a material. Through collaborative sources and supported by students' understanding (shared knowledge), quality knowledge 
construction will be obtained (Shin et al., 2018).

There are additional recommendations from material experts, namely on case studies and types of disasters provided in this teaching material. The case study given in teaching materials is focused on one of the administrative areas in Malang Regency, namely Lawang District. For disasters, the teaching material uses one of the natural disasters, namely landslides.

Based on the results of validation by material experts, the teaching material prototype was declared feasible to be applied in class. The final decision given by the material expert was
"Feasible for use in the field without any revisions". This is due to the improvement of teaching materials is under the guidance of material experts before a final decision is given.

\section{The Validation Result of Design Expert}

Design validation aims to assess the appearance of teaching materials. This assessment is intended to provide an attractive face to face or visually to the reader so as not to be boring. In addition, visuals also provide clarity in understanding a material that affects students' learning experiences(Hautopp \& Buhl, 2020). Design expert provides the eligibility assessment criteria which consist of the following.

Table 3. Assessment Items of the Design Expert

\begin{tabular}{cc}
\hline No & Assessment Items \\
\hline 1 & Picture \\
\hline 2 & Layout \\
\hline 3 & Cover \\
\hline 4 & Landscape mode image / map placement \\
\hline 5 & Text dan font \\
\hline 6 & Margin \\
\hline
\end{tabular}

To meet the feasibility of the design, the revision is carried out in their entirety based on the items above. Layout is an item that is highly considered in this design revision. This is due to the layout is associated with the arrangement of elements that are on each page of teaching materials. The print model uses option of the mirror margins, thus it requires a different arrangement of images and maps on each page.

Cover undergoes a few changes from the previous prototype. This change is in the form of elements on the 
cover, namely the placement of the writing, the fields used, image transitions, and writing of blurbs or pieces of the contents of the book. Changes to the cover have reasons to clarify the identity of the book created. This cover takes into consideration the choice of reading and content by readers (Gudinavičius \& Šuminas, 2018).

Based on the result of validation by design expert, the prototype of teaching materials is declared feasible to be applied in class. The final decision given by the material expert is "Feasible to be used in the field with revision". Design expert emphasizes the good message and face-to-face delivery of this resource.
Revisions undertaken are related to the arrangement of the supporting elements of the teaching materials.

\section{Validation Results of the Linguist}

Language validation is used to find out the correctness of the language in writing in teaching materials. Language is an important element in achieving understanding of a reading. The language used, including the interpretation of the reader's background knowledge, is used to access the meaning of the text (Kaygisiz, 2019). Feasibility data is obtained from assessments based on criteria given by linguists.

Table 4. Assessment Items of Linguist

\begin{tabular}{cl}
\hline No & \multicolumn{1}{c}{ Assessment Items } \\
\hline 1 & Quote \\
\hline 2 & Sentence Numbering \\
\hline 3 & The use of capital letters \\
\hline 4 & Structure sentences and paragraphs \\
\hline 5 & Punctuation \\
\hline 6 & The Selection of Picture \\
\hline 7 & The linkage of writing to the subject \\
\hline
\end{tabular}

The sentence structure and paragraph arrangement to be greater concern for the linguists. The thing that is most highlighted is the effectiveness of sentences, explanations, and the number of paragraphs. In the sentence structure, there is a reduction in excessive words and an addition of conjunctions. Explanation is shortened to avoid over understanding.

The improvement of image selection adapted to the context of the writing. Images have an important role in the infographic elements contained in 
writing. Like shapes, symbols and graphics, images have a role in conveying messages from the author to the reader (Ozdamli \& Ozdal, 2018). Therefore, the existence of image elements must be side by side with the context of the writing.

Based on the results of validation by linguists, the prototype of teaching materials was declared feasible to be applied in class. The final decision given by the material expert was "Feasible to be used in the field with revision". The sentence structure and paragraph arrangement are the most basic benchmarks on the assessment of the linguist. Improvements were conducted in various aspects, especially on comprehension, sentence effectiveness, and overall grammar.

\section{The Result of Product Trial}

Product trial activities were carried out by class XI of IPS 1 students at SMA Negeri 1 Lawang. Response questionnaires were used to obtain responses from students. Student response data were obtained from 10 questions and a suggestion column. Data on the results of student responses can be seen in the table below.

Table 5. Data on Total Frequency Distribution of Student Questionnaire Scores

\begin{tabular}{cclcc}
\hline Classification & Score Range & Qualification & Frequency & Percentage \\
\hline A & $85,01-100,00$ & Very valid & 1 & $2,78 \%$ \\
\hline B & $70,01-85,00$ & Quite valid & 35 & $97,22 \%$ \\
\hline C & $50,01-70,00$ & Less valid & 0 & 0 \\
\hline D & $1,00-50,00$ & Invalid & 0 & 0 \\
\hline & Total & & 36 & $100 \%$ \\
\hline
\end{tabular}

Based on the table above, students give a positive response which shows that $2.78 \%$ states very valid and $97.22 \%$ is quite valid. From the total 36 students, one student responds very well and is motivated to read the teaching materials, while the remaining of 35 students give a quite well respond. These results indicate that this teaching material is quite suitable for use in learning.

For details on the score for each aspect of the questions given in the questionnaire, it can be seen in the following table. 
Table 6. The Results of Student Responses on Teaching Materials

\begin{tabular}{|c|c|c|c|}
\hline No & Aspect & Assessment Items & core \\
\hline \multirow{4}{*}{1} & \multirow[b]{2}{*}{ Design } & The writing is clear and easy to read & 133 \\
\hline & & $\begin{array}{l}\text { Understanding on the messages or } \\
\text { information }\end{array}$ & 117 \\
\hline & & Total & 250 \\
\hline & & Percentage & $86,80 \%$ \\
\hline \multirow{6}{*}{2} & \multirow{4}{*}{ Language } & The sentences used can motivate the reader & 109 \\
\hline & & $\begin{array}{l}\text { The depth / detailed explanation of the } \\
\text { material }\end{array}$ & 120 \\
\hline & & Accuracy of data and facts & 119 \\
\hline & & Writing terms are easy to be understood & 123 \\
\hline & & Total & 471 \\
\hline & & Percentage & $81,77 \%$ \\
\hline \multirow{6}{*}{3} & \multirow{4}{*}{ Content } & Book can facilitate to learn & 132 \\
\hline & & The material explanation is coherent & 121 \\
\hline & & $\begin{array}{l}\text { The breadth explanation of environmental } \\
\text { and local wisdom }\end{array}$ & 122 \\
\hline & & $\begin{array}{l}\text { The implementation of the material in } \\
\text { everyday life }\end{array}$ & 117 \\
\hline & & Total & 492 \\
\hline & & Percentage & $85,42 \%$ \\
\hline
\end{tabular}

In the design aspect, students give a response score of 250 with a percentage of $86.80 \%$. This percentage shows that the product is very feasible in the design aspect.In the language aspect, students give an average score of 471 with a percentage of $81.77 \%$. This percentage indicates that the product is the classification of quite feasible. In the material aspect, students give an average score of 492 with a percentage of $85.42 \%$. This percentage indicates that the product is the classification of very feasible.

Based on student responses, teaching material products can be well received. In addition, teaching materials can be redeveloped by deepening the content presented. For students, this product got a positive response and it can motivate learning in relation to disaster topic.

The Advantages and Disadvantages of Product

Based on the evaluation at each stage as well as the product results, it was found several advantages and disadvantages of this teaching material. The advantages referred to, namely: 1) teaching materials of local wisdom and environment are still rarely found, 2) interesting book concepts, 3) quite 
detailed case studies, 4) presentation of local wisdom is quite in-depth, 5) simple explanation, 6) the ease of use for information and communication technology. Besides having advantages, this teaching material also has disadvantages. These deficiencies cover: 1) the focus of the disaster is only on landslides, 2) the coverage of a narrow area, 3 ) and the deepening of content that requires further research.

\section{CONCLUSIONS}

Based on the discussion, the research product in the form of teaching material can be declared that it was feasible to be applied in learning. The assessment of the expert, in general, the prototype is given a decision, that is, it is feasible to be used in the field with some improvements. Then, this prototype was applied in the field to obtain further feasibility. The implementation was undertaken to students by providing a questionnaire which contained of the aspects of the material, design, and language. In the material aspect, students gave a percentage of $85.42 \%$ which can be classified as very feasible. The design aspect obtained was $86.80 \%$ with a very feasible classification, while the language aspect got $81.77 \%$ which was quite feasible. Regarding to the percentage results, this product received a positive response from the students, thus, it was quite feasible to be implemented in learning. Teaching material products from development research can be an alternative source of learning in addition to using other textbooks.

\section{E. ACKNOWLEDGMENTS}

Thanks to LP2M UM (Institute for Research and Community Service, State University of Malang) for funding the sustainability of this journal.

\section{F. REFERENCES}

Aka, K. A. (2019). Integration Borg \& Gall (1983) and Lee \& Owen (2004) models as an alternative model of design-based research of interactive multimedia in elementary school. Journal of Physics: Conference Series, 1318(1). https://doi.org/10.1088/17426596/1318/1/012022

Akbar, S. (2013). Intrumen Perangkat Pembelajaran (1st ed.). Rosdakarya.

Butzer, K. W. (1982). Archaeology as Human Ecology. In Archaeology as Human Ecology. https://doi.org/10.1017/cbo97805 11558245

Desfandi, M. (2014). Urgensi Kurikulum Pendidikan Kebencanaan Berbasis Kearifan Lokal di Indonesia [The urgency of disaster education curriculum based on local wisdom in 
Indonesia\}. Sosio Didaktika Sosial Science Education Journal, 1(2).

Dewanti, D. S., Ayuwat, D., \& Yongvanit, S. (2019). Household disaster management capacities in disaster prone II area of Mt. Slamet. Jamba: Journal of Disaster Risk Studies, 11(1), 1-8. https://doi.org/10.4102/jamba.v1 1i1.649

Dewi, D. R., \& Hamami, T. (2019). Pengembangan Kurikulum di Indonesia Menghadapi Tuntutan Kompetensi Abad Ke-21. AsSalam I, 7.

Gudinavičius, A., \& Šuminas, A. (2018). Choosing a book by its cover: analysis of a reader's choice. Journal of Documentation, 74(2), 430-446.

https://doi.org/10.1108/JD-092016-0111

Hautopp, H., \& Buhl, M. (2020). Teaching visual facilitation and sketching for digital learning design in higher education. Proceedings of the European Conference on E-Learning, ECEL, 2020-Octob, 235-242. https://doi.org/10.34190/EEL.20. 025

Kaygisiz, Ç. (2019). Applied linguistics perspective in developing reading material. Pegem Egitim ve Ogretim Dergisi, 9(4), 10631080.

https://doi.org/10.14527/pegegog. 2019.034

Ozdamli, F., \& Ozdal, H. (2018). Developing an instructional design for the design of infographics and the evaluation of infographic usage in teaching based on teacher and student opinions. Eurasia Journal of Mathematics, Science and
Technology Education, 14(4), 1197-1219. https://doi.org/10.29333/ejmste/8 1868

Parmin, Sajidan, Ashadi, Sutikno, \& maretta, Y. (2016). Preparing prospective teachers in integrating science and local wisdom through practicing open inquiry. Journal of Turkish Science Education, 13(2), 3-14. https://doi.org/10.12973/tused.10 $163 \mathrm{a}$

Pornpimon, C., Wallapha, A., \& Prayuth, C. (2014). Strategy Challenges the Local Wisdom Applications Sustainability in Schools. Procedia - Social and Behavioral Sciences, 112(Iceepsy 2013), 626-634. https://doi.org/10.1016/j.sbspro.2 014.01.1210

Prastowo, A. (2015). Panduan Kreatif Membuat Bahan Ajar Kreatif. Diva Press.

Saglam, H. I. (2011). An investigation on teaching materials used in social studies. Turkish Online Journal of Educational Technology, 10(1), 36-44.

Setyosari, P. (2013). Metode Penelitian Pendidikan dan Pengembangan. Kencana Prenada Media Group.

Shin, Y., Kim, D., \& Jung, J. (2018). The effects of representation tool (visible-annotation) types to support knowledge building in computer-supported collaborative learning. Educational Technology and Society, 21(2), 98-110.

Suarmika, P. E., \& Utama, E. G. (2017). Pendidikan Mitigasi Bencana di Sekolah Dasar. Jurnal Pendidikan Dasar Indonesia, 2(September), 18-24.

Subandi, A., Alim, S., Haryanti, F., \& 
Prabandari, Y. S. (2019). Training on modified model of programme for enhancement of emergency response flood preparedness based on the local wisdom of Jambi community. Jàmbá Journal of Disaster Risk Studies, 11(1), 110.

https://doi.org/10.4102/jamba.v1 1i1.801

Sugiyono. (2016). Metode Penelitian Pendidikan (23rd ed.). CV Alfabeta. www.cvalfabeta.com

Sulistyowati, P., \& Putri, N. M. (2018). Pengembangan Bahan Ajar Modul Berbasis Contextual Teaching and Learning (CTL) Kelas IV Tema 3 Subtema 1.
Jurnal Pendidikan (Teori Dan Praktik), 3(1), 1. https://doi.org/10.26740/jp.v3n1. p1-6

Tanjung, A., \& Fahmi, M. (2015). URGENSI PENGEMBANGAN BAHAN AJAR GEOGRAFI BERBASIS KEARIFAN LOKAL. Jurnal Pendidikan Geografi, 1, 1-6. https://doi.org/10.1017/CBO9781 107415324.004

Thamrin, H. (2013). Kearifan Lokal dalam Pelestarian Lingkungan ( The Lokal Wisdom in Environmental Sustainable ). Kutubkhanah, 16(1), 46-59. 